\title{
PENGARUH JENIS PELARUT TERHADAP JUMLAH EKSTRAK DAN DAYA ANTIFUNGI DAUN KETEPENG CINA (CASSIA ALATA L.) TERHADAP JAMUR TRYCHOPHYTON SP
}

\author{
Zona Octarya, Robi Saputra \\ Program Studi Pendidikan Kimia UIN SUSKA Riau \\ Email; souvenirznoc@yahoo.co.id
}

\begin{abstract}
ABSTRAK
Ketepeng cina ( Cassia alata L. ) berasal dari daerah tropik Amerika dan biasanya hidup pada dataran rendah sampai pegunungan dengan ketinggian 1.400 meter di atas permukaan laut. Penelitian ini dilakukan untuk mengetahui pengaruh jenis pelarut terhadap jumlah ekstrak dan daya antifungi dari ekstrak daun ketepeng cina terhadap jamur Trychophyton sp.. Telah dilakukan penelitian yang meliputi pembuatan serbuk simplisia, skrining fitokimia, ekstraksi serbuk simplisia, dan uji aktivitas antifungi ekstrak daun ketepeng cina. Skrining fitokimia serbuk simplisia menunjukkan bahwa serbuk daun ketepeng cina mengandung senyawa flavonoid, alkaloid, antrakuinon, saponin dan tanin. Ekstraksi serbuk daun ketepeng cina dilakukan dengan metode refluks menggunakan pelarut etanol 70\%, n-heksana dan aquades. Metode difusi agar dilakukan untuk mengetahui ekstrak terbaik serbuk daun ketepeng cina terhadap penghambatan pertumbuhan jamur Trychophyton mentagrophytes dengan meneteskan ekstrak dan sebagai pembanding digunakan antibiotik ketokonazol 2\% dan kontrol negatif berupa pelarut. Hasil uji aktivitas antifungi menunjukkan ekstrak etanol daun ketepeng memberikan diameter zona bening yang paling besar dibandingkan dengan ekstrak n-heksana dan aquades dengan ukuran diameter zona bening rata-rata $20,06 \mathrm{~mm}$.
\end{abstract}

Kata Kunci: Ketepeng Cina (Cassia alata L.), Skrining Fitokimia, Metabolit Sekunder, Ekstraksi, Antifungi

\section{PENDAHULUAN}

Sejak zaman dahulu nenek moyang kita telah menggunakan berbagai tanaman sebagai obat tradisional untuk mengobati berbagai jenis penyakit. Banyak diantara tanaman tersebut tidak diperhatikan dan terkesan tumbuh sebagai tumbuhan liar. Diantara tanaman yang digunakan sebagai tanaman obat tradisional oleh masyarakat yang tinggal di daerah yang jauh dari kota atau yang jauh dari toko obat dan apotek untuk mengobati penyakit panu, kurap dan sebagainya adalah daun tumbuhan ketepeng cina.

Tumbuhan ketepeng cina mempunyai nama ilmiah Cassia alata L. Tumbuhan ini ternyata mempunyai banyak khasiatnya di samping untuk pengobatan penyakit akibat infeksi jamur. Dari beberapa hasil penelitian terdahulu telah terbukti bahwa ekstrak daun ketepeng cina berpengaruh terhadap pertumbuhan jamur, juga mempengaruhi perkembangan cacing perut, dapat mengatasi sembelit dan masih banyak lagi manfaat farmakologi lainnya. Hal itu disebabkan oleh adanya kandungan zat antimikrobial yang bersifat fungistatik di dalamnya, sehingga dapat menghambat proses pemanjangan hifa (misellium) jamur dan akhirnya perkembangan jamur pun menjadi terhambat (Hujjatusnaini).

Daun Ketepeng cina ( Cassia alata L. ) dapat digunakan sebagai obat secara tradisional disebabkan oleh adanya kandungan kimia yang terdapat didalamnya seperti rein aloe emodina, rein aloe emodina diantron, asam krisofanat (dehidroksimetil antroquinone) dan tannin. Di samping itu alkaloida, flavonoida juga terdapat di dalamnya (Syamsuhidayat, Ria, 1991). Dari beberapa penelitian terdaulu diketahui bahwa senyawa yang bersifat sebagai antifungi dan anti parasit dalam daun ketepeng cina adalah senyawa antrakuinon asam krisofanat(Wijoyo, 2008).

Penyakit panu merupakan penyakit infeksi kulit yang disebabkan oleh beberapa jenis jamur, diantaranya adalah jamur Trichophyton $s p$. Jamur Trichophyton $s p$ dapat menyebabkan penyakit kulit pada manusia seperti panu, kadas dan kurap, dengan gambaran klins berupa permukaan kulit yang tampak seperti bulatan- 
bulatan kecil dengan pinggiran merah dan bersisik serta bagian tengahnya yang tampak licin tanpa rambut pada daerah infeksinya (Hembing, 1996). Infeksi akibat jamur Trichophyton $s p$ ini bersifat menular, yang penularannya melalui tiga tahapan yaitu kontaminasi, kolonisasi dan parasitasi (Dwidjoseputro, 1978).

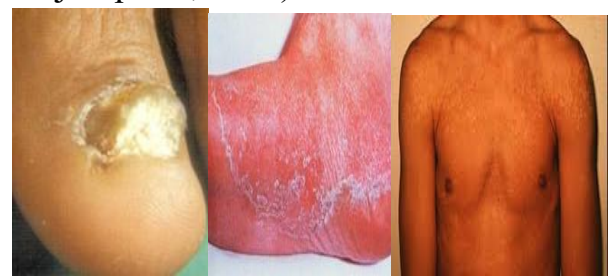

Gambar. 8 Penyakit Akibat Infeksi Jamur Trichophyton $s p$ (a. Tinea unguinum (onikomikosis), b. Tinea manus, c. Tinea versikolor (panu))

Secara tradisional, untuk pengobatan penyakit yang disebabkan oleh jamur, masyarakat melakukan pengobatan dengan cara melumatkan daun ketepeng cina yang segar dengan tambahan sedikit minyak tanah, air dan beberapa bahan tambahan lainnya seperti kapur sirih. Namun, secara laboratoris belum diketahui jenis dan konsentrasi pelarut serta suhu dan metode yang tepat untuk mengekstrak daun ketepeng cina. Dengan dasar tersebut, maka peneliti tertarik untuk melakukan penelitian tentang daun ketepeng cina dengan cara mengekstrak dengan metode refluks dengan menggunakan pelarut etanol, n-heksana dan aquades. Sehingga tujuan penelitian ini adalah untuk mengetahui pengaruh jenis pelarut terhadap jumlah ekstrak dan daya antifungi daun ketepeng cina (Cassia alata L) terhadap jamur Trichophyton $s p$.

\section{METODOLOGI PENELITIAN}

\section{Alat dan Bahan}

Alat

Alat-alat yang digunakan pada penelitian ini adalah seperangkat alak ekstraksi refluks, oven, rotari evaporator, inkubator, autoclafe, timbangan analitis, blender/ penggiling, ayakan ukuran 100 mesh, tabung reaksi, kawat ose, spatula, kertas saring, cawan petri dan lampu bunsen.

\section{Bahan}

Bahan yang digunakan dalam penelitian ini adalah jamur Trichophyton mentagrophytes, daun ketepeng cina, etanol $70 \%$, n-heksana, akuades, $\mathrm{KOH} 30 \%, \mathrm{HgCl}, \mathrm{KI}$, asam asetat, asam sulfat, $\mathrm{FeCl}_{3}$, sebuk $\mathrm{Mg}, \mathrm{H}_{2} \mathrm{O}_{2}$, amoniak, $\mathrm{HCl}$, ketokonazol 2\%, PDA dan batu es.

\section{Prosedur Penelitian}

a. Pengambilan dan Pengolahan Sampel

Daun ketepeng cina segar diambil sebanyak $4 \mathrm{~kg}$. Kemudian dikeringkan dalam oven pada suhu $50 \quad{ }^{\circ} \mathrm{C}$ selama 3-4 hari. Dilakukan penimbangan dengan menggunakan timbangan teknis hingga berat konstan. sampel kering diblender sampai halus dan diayak dengan ayakan dengan ukuran 100 mesh. Hasil pengayakan yang berupa serbuk simplisia disimpan dalam erlenmeyer (Sihombing, 2005).

b. Pembuatan Larutan Pereaksi

1. Larutan Pereaksi Meyer

Pereaksi Meyer terdiri dari: larutan pertama (1,358 $\mathrm{g} \mathrm{HgCL}_{2}+60 \mathrm{ml}$ akuades) dan larutan kedua (5 g KI $+10 \mathrm{ml}$ akuades). Tuangkan larutan yang pertama kedalam larutan yang kedua, diencerkan dengan menggunakan aquades sampai batas $100 \mathrm{ml}$. Pereaksi ini merupakan pereaksi untuk hampir semua alkaloida dengan membentuk endapan putih dalam suasana sedikit asam (Mulyono, 2009).

2. Larutan Pereaksi Liebermann-Burchard

Pereaksi Liebermann-Burchard terdiri dari anhidrida asam asetat (p.a) dan asam sulfat (p.a) dengan perbandingan 3:1 (Siadi, 2012).

3. Pereaksi Besi (III) Klorida $1 \%$

$1 \mathrm{~g} \mathrm{FeCl}_{3}$ dilarutkan dalam akuades hingga volume $100 \mathrm{ml}$, larutan dipindahkan kedalam erlenmeyer.

c. Skrining Fitokimia Ekstrak Daun Ketepeng Cina

Skrining fitokimia dilakukan untuk mengetahui jenis senyawa metabolit sekunder yang terdapat dalam daun ketepeng cina.

\section{Flavonoid}

Sebanyak $1 \mathrm{~g}$ serbuk simplisia ditambahkan dengan etanol 95\% sampai semua sampel terendam dan dipanaskan. 
Lapisan atas dipipet dan ditambahkan dengan $\mathrm{HCl}$ pekat $2 \mathrm{~N}$ dan serbuk $\mathrm{Mg}$. Jika terbentuk endapan warna merah, maka sampel positif mengandung flavonoid.

\section{Alkaloid}

Sebanayak $4 \quad \mathrm{~g}$ sampel kering ditambahkan kloroform secukupnya, kemudian ditambahkan $10 \mathrm{ml}$ amoniak dan $10 \mathrm{ml}$ kloroform. Larutan disaring kedalam tabung reaksi dan filtratnya ditambahkan 10 tetes $\mathrm{H}_{2} \mathrm{SO}_{4} 2 \mathrm{~N}$. Campuran dikocok dengan teratur dan dibiarkan beberapa menit sampai terbentuk 2 lapisan. Lapisan atas dipipet sebanyak $1 \mathrm{ml}$ dan dimasukkan kedalam tabung reaksi dan di tambahkan beberapa tetes pereaksi Meyer. Apabila terbentuk endapan putih, maka sampel positif mengandung alkaloid (Mulyono, 2009).

\section{Steroid, Triterpenoid dan Saponin}

Sebanyak $10 \quad \mathrm{~g}$ sampel diekstraksi dengan metanol panas, disaring dan dipekatkan. Ekstrak metanol diekstraksi dengan dietil eter. Ekstrak yang larut diuji dengan reagen Libermann-Burchard. Warna biru menunjukkan positif steroid dan warna merah positif triterpenoid. Ekstrak yang tidak larut kemudian dilarutkan dalam air dan dikocok. Apabila terdapat busa yang stabil selama \pm 30 menit, ini menunjukkan positif saponin (Oesman, 2010).

\section{Antrakuinon}

Sebanyak $1 \mathrm{~g}$ ekstrak ditambah $10 \mathrm{ml}$ $\mathrm{KOH}$ 0,5 M dan $1 \mathrm{ml}$ hidrogen peroksida 5\% dipanaskan selama 10 menit, kemudian disaring, diasamkan dengan asam asetat, dan diekstraksi dengan $5 \mathrm{ml}$ benzena. Lapisan benzena dipisahkan dan ditambahkan amoniak. Hasil positif ditunjukkan jika pada lapisan amoniak terbentuk warna merah dan lapisan benzena tidak berwarna (Mangunwardoyo, 2009).

\section{Tanin}

Sampel sebanyak $20 \mathrm{mg}$ ditambahkan dengan etanol sampai semua sampel terendam. Kemudian ditambahkan 2-3 tetes larutan $\mathrm{FeCl}_{3}$ $1 \%$. Jika terbentuk warna hitam kebiruan atau hijau menunjukkan sampel positif mengandung tanin (Marlinda, 2012).

\section{d. Pembuatan Media PDA}

Sebanyak 3,9 gram PDA bubuk dilarutkan dalam $100 \mathrm{ml}$ akuades. diaduk dan kemudian dimasukkan ke dalam autoclafe dan di panaskan pada suhu $121^{\circ} \mathrm{C}$ selama 15 menit. Kemudian PDA yang telah larut dituangkan ke dalam 3 cawan petri yang telah di sediakan pada laminar flow. Tuangkan PDA cair dan didinginkan serta di sterilisasi dalam laminar flow dengan menggunakan lampu UV.

e. Ekstraksi Refluks

Sebanyak $50 \mathrm{~g}$ serbuk simplisia dibungkus dengan kertas saring dan diikat. Kemudian simplisia dimasukkan kedalam labu alas bulat dan ditambahkan 1 liter etanol. Atur suhu sesuai titik didih etanol $\left(78{ }^{\circ} \mathrm{C}\right)$ dan jalankan proses ekstraksi refluks selama 2 jam. Lakukan penggantian pelarut sebanyak 2 kali setiap 2 jam. Ekstrak yang didapatkan dipekatkan dengan rotari evaporator. Langkah ini dilakukan untuk jenis pelarut n-heksana (titik didih $69^{\circ} \mathrm{C}$ ) dan akuades (titik didih $100{ }^{\circ} \mathrm{C}$ ).

f. Penentuan Pengaruh Jenis Pelarut Terhadap Jumlah Ekstrak Daun Ketepeng Cina

Penentuan pengaruh jenis pelarut terhadap jumlah ekstrak dilakukan dengan cara membandingkan berat awal simplisia dengan berat kering ekstrak yang didapat dengan rumus:

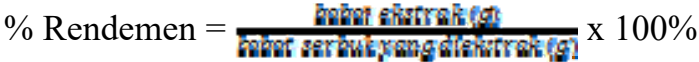

Pelarut dengan \% rendemen terbesar merupakan pelarut yang paling baik untuk ekstraksi daun ketepeng cina.

g. Penentuan Pengaruh Jenis Pelarut Terhadap Daya Antifungi Ekstrak Daun Ketepeng Cina

Penentuan pengaruh jenis pelarut terhadap daya antifungi dilakukan dengan metode difusi agar. Metode difusi pada lempeng agar digunakan untuk melihat adanya aktivitas antifungi dari hasil ekstraksi daun ketepeng cina. Ekstrak etanol, n-heksana, aquades, kontrol positif (ketokonazol 2\% ) dan kontrol negatif (etanol, n-heksana dan aquades tanpa ekstrak) sebanyak $0,1 \mathrm{ml}$ di pipet dan di teteskan kedalam sumuran yang telah dibuat dengan diameter 7 $\mathrm{mm}$ pada permukaan media PDA yang mengandung inokulum jamur, kemudian 
diinkubasi selama 48 jam pada suhu $30{ }^{\circ} \mathrm{C}$. Daerah hambatan diukur berdasarkan zona bening yang terbentuk dengan penggaris berskala. Pengulangan dilakukan sebanyak 3 kali (Mangunwardoyo, 2009).

$$
\text { Diameter zona hambat }=\frac{\not 1+D g+\sigma q}{\mathfrak{d}}
$$

Dimana: $\mathrm{D}_{1}, \mathrm{D}_{2}, \mathrm{D}_{3}$ adalah areal bening $(\mathrm{mm})$.

\section{HASIL DAN PEMBAHASAN}

Dari $4 \mathrm{~kg}$ daun ketepeng cina segar yang dikeringkan, berat serbuk simplisia yang di dapatkan adalah sebanyak 821,12 gr. Skrining fitokimia dilakukan secara kualitatif untuk menentuakn kandungan senyawa metabolit sekunder dari daun ketepeng cina. Hasil skrining fitokimia dari serbuk simplisia daun ketepeng cina disajikan dalam tabel 5.

Dari 3 L jumlah ekstrak untuk setiap pelarut dilakukan pemekatan dengan rotari evavorator dan juga dengan magnetik stirer. Jumlah \% rendemen ekstrak pekat yang didapatkan adalah 13,64 \% untuk pelarut aquades, 12,06\% untuk pelarut etanol dan 9,7\% untuk pelarut n-heksana. Ekstrak yang didapatkan selanjutnya akan digunakan untuk penentuan aktivitas daya antifungi.

Tabel. 5. Hasil Skrining Fitokimia Daun

\begin{tabular}{|l|l|c|l|}
\hline No & \multicolumn{1}{|c|}{$\begin{array}{c}\text { Golongan } \\
\text { senyawa }\end{array}$} & Hasil & \multicolumn{1}{|c|}{ Karakteristik } \\
\hline 1 & Flavonoid & + & $\begin{array}{l}\text { Terbentuk endapan } \\
\text { merah }\end{array}$ \\
\hline 2 & Alkaloid & ++ & $\begin{array}{l}\text { Terbentuk endapan } \\
\text { putih }\end{array}$ \\
\hline 3 & Steroid & - & $\begin{array}{l}\text { Tidak terbentuk } \\
\text { warna biru }\end{array}$ \\
\hline 4 & Triterpenoid & - & $\begin{array}{l}\text { Tidak terbentuk } \\
\text { warna merah }\end{array}$ \\
\hline 5 & Saponin & +++ & $\begin{array}{l}\text { Terbentuk busa } \\
\text { stabil } \pm 30 \text { menit }\end{array}$ \\
\hline 6 & Antrakuinon & +++ & $\begin{array}{l}\text { Lapisn benzen tidak } \\
\text { berwarna dan } \\
\text { lapisan amoniak } \\
\text { berwarna merah }\end{array}$ \\
\hline 7 & Tanin & ++ & $\begin{array}{l}\text { Terbentuk warna } \\
\text { hijau }\end{array}$ \\
\hline
\end{tabular}

Keterangan: $(+)$ Terdeteksi dan

( - )Tidak terdeteksi

Hasil pengukuran diameter zona bening aktivitas antifungi ekstrak daun ketepeng cina dengan pelarut aquades, etanol dan n-heksana ditampilkan dalam table 2 .
Penentuan pengaruh pelarut terhadap jumlah ekstrak dilakukan dengan cara penimbangan ekstrak kental hasil ekstraksi dan kemudian dihitung \% rendemen yang dihasilkan oleh masing-masing pelarut. Dari hasil perhitungan dan perbandingan $\%$ rendemen yang dihasilkan, pelarut yang terbaik untuk ekstraksi adalah akuades dengan \% rendemen sebanyak $13,64 \%$. Apabila dilihat dengan kasat mata, maka akan terlihat jumlah ekstrak yang dihasilkan dengan urutan ekstrak n-heksana lebih besar dari ekstrak etanol, ekstrak etanol lebih besar dari ekstrak akuades. Tetapi hasil penimbangan dan perhitungan $\%$ rendemen yang dihasilkan adalah sebaliknya. Hal ini dapat terjadi karena adanya

\begin{tabular}{|c|l|c|c|c|c|}
\hline \multirow{2}{*}{ No } & \multirow{2}{*}{$\begin{array}{c}\text { Jenis } \\
\text { Ekstrak }\end{array}$} & \multicolumn{3}{|c|}{ Banyak Pengulangan } & $\begin{array}{c}\text { Rata- } \\
\text { rata } \\
\text { (mm) }\end{array}$ \\
\cline { 3 - 6 } & $\begin{array}{c}\mathbf{1} \\
(\mathbf{m m})\end{array}$ & $\begin{array}{c}\mathbf{2} \\
(\mathbf{m m})\end{array}$ & $\begin{array}{c}\mathbf{3} \\
(\mathbf{m m})\end{array}$ & \\
\hline 1 & $\begin{array}{l}\text { Ekstrak } \\
\text { akuades }\end{array}$ & 18,30 & 12,20 & 13,40 & 14,63 \\
\hline 2 & $\begin{array}{l}\text { Ekstrak } \\
\text { etanol }\end{array}$ & 25,40 & 16,30 & 18,50 & 20,06 \\
\hline 3 & $\begin{array}{l}\text { Ekstrak n- } \\
\text { heksana }\end{array}$ & 16,60 & 11,40 & 15,70 & 16,56 \\
\hline 4 & Akuades & - & - & - & - \\
\hline 5 & $\begin{array}{l}\text { Etanol } \\
70 \%\end{array}$ & 14,80 & 13,30 & 14,60 & 14,23 \\
\hline 6 & n-heksana & - & - & - & - \\
\hline 7 & $\begin{array}{l}\text { Ketokona } \\
\text { zol } \%\end{array}$ & 35,20 & 38,40 & 41,20 & 38,26 \\
\hline
\end{tabular}

pengaruh berat jenis dari masing-masing pelarut. Ketika proses pemekatan, tidak semua pelarut yang terpisahkan. Air memiliki berat jenis lebih besar dari pada etanol dan n-heksana, hal ini yang menyebabkan \% rendemen lebih besar.

\section{Tabel 2. Hasil Pengukuran Zona Bening}

Penentuan pengaruh pelarut terhadap daya antifungi dilakukan dengan metode difusi agar. Masing-masing ekstrak, kontrol positif dan kontrol negatif di teteskan pada permukaan media PDA yang terdapat koloni jamur dengan diameter sekitar $7 \mathrm{~mm}$. Kemudian di inkubasi pada suhu $30^{\circ} \mathrm{C}$ selama 4 hari dalam inkubator.

Hasil yang didapatkan adalah masingmasing ekstrak memberikan daerah zona bening dengan ukuran yang berbeda. Ekstrak yang memberikan zona bening terbesar adalah ekstrak dengan pelarut etanol dengan rata-rata diameter zona bening 20,06 mm. Hasil diameter zona 
bening masing-masing pelarut dapat dilihat pada gambar II.

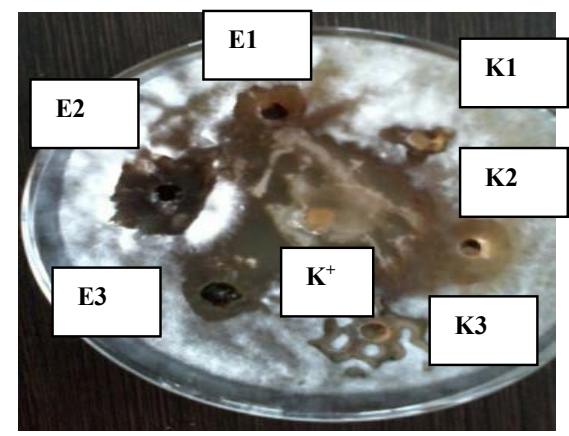

Gambar II. 6 Zona Bening Ekstrak Daun Ketepeng Cina; $E_{1}$. Ekstrak Aquades, $E_{2}$. Ekstrak Etanol, E 3 . Ekstrak n-heksana, $\mathrm{K}^{+}$. Ketokonazol $2 \%, \mathrm{~K}_{1}^{-}$. Aquades, $\mathrm{K}_{2}^{-}$. Etanol, $\mathrm{K}_{3}^{-}$. N-heksana

Ekstrak akuades memberikan diameter zona bening dengan rata-rata $14,63 \mathrm{~mm}$. Sedangkan ekstrak dengan pelarut n-heksana memberikan diameter zona bening $14,56 \mathrm{~mm}$. Perbedaan ini terjadi disebabkan oleh beberapa faktor, yaitu:

\section{Kepolaran pelarut}

Kepolaran pelarut yang digunakan akan mempengaruhi proses difusi ekstrak ke dalam medium PDA. Medium PDA yang dibuat dengan melarutkan PDA bubuk kedalam aquades yang bersifat polar, akan mudah berinteraksi dengan cara difusi dengan ekstrak yang menggunakan pelarut yang polar juga. Ekstrak dengan pelarut yang polar tersebut akan lebih mudah masuk kedalam media PDA dan proses penghambatan pertumbuhan koloni jamur akan lebih maksimal.

2. Jumlah komponen aktif antifungi yang terekstrak oleh pelarut

Kemampuan suatu pelarut untuk mengekstrak senyawa aktif yang berperan sebagai anti jamur atau antifungi akan memberikan diameter zona bening yang berbeda. Apabila komponen senyawa aktif yang dapat di ekstrak besar, maka ekstrak memberikan diameter zona bening yang lebih besar. Sebaliknya, apabila komponen senyawa aktif yang dapat di ekstrak sedikit, maka diameter zona hambat yang diberikan akan lebih kecil. Senyawa aktif yang berperan sebagai antimikroba dalam ekstrak daun ketepeng cina yaitu senyawa antrakuinon, flavonoid, saponin dan tanin.

\section{Kemampuan suatu pelarut} sebagai antimikroba.

Senyawa alkohol bersifat sebagai antimikroba. Senyawa alkohol yang dapat digunakan sebagai bahan antimikroba adalah metanol, etanol dan isopropanol. Senyawa alkohol akan memecah struktur lipid sehingga dapat mendenaturasi atau merusak protein seluler. Oleh karena itu membran sel akan rusak dan enzim-enzim mengalami inaktivasi.

\section{Umur mikroba}

Mikroba yang berumur masih muda (stasioner) akan lebih mudah untuk mengalami denaturasi protein membran sel dan menyebabkan perkembangan pertumbuhan koloni akan lebih kecil. Sedangkan mikroba yang berumur tua (eksponensial) akan lebih rentan terhadap senyawa lain yang dapat merusak dinding selnya. Kerentanan ini menyebabkan pertumbuhan mikroba tersebut tidak akan terhalang (Soedarmin, 2012).

Hal ini dapat terjadi karena adanya adaptasi dan mutasi gen yang terjadi ketika proses berlansung, sehingga gen-gen mikroorganisme akan lebih labih rentan dan tahan terhadap suatu antimikroorganisme.

\section{KESIMPULAN DAN SARAN}

Efikasi diri merupakan salah satu aspek yang diperlukan bagi pasien diabetes tipe 2 untuk meningkatkan kemandirian pasien dalam mengelola penyakitnya, dan manajemen diri merupakan bagian terpenting dari perawatan diabetes, karena manajemen diri pada diabetes menggabungkan antara faktor perilaku, faktor individu, dan dan faktor lingkungan ke dalam kegiatan sehari-hari yang telah direkomendasikan untuk pasien diabetes. Efikasi diri dan manajemen diri pada pasien diabetes merupakan dua komponen penting sebagai dasar untuk mencegah komplikasi terkait penyakit dan mempertahankan kualitas hidup. Perubahan perilaku dan gaya hidup biasanya sulit dilakukan bagi penderita diabetes, sehingga diperlukan pendekatan yang komprehensif dalam mengembangkan program perubahan perilaku yang melibatkan faktor-faktor tersebut.

\section{DAFTAR PUSTAKA}


Al-Khawaldeh, O. A., Al-Hassan, M. A., \& Froelicher, E.S. (2012). Self-efficacy, self-management, and glycemic control in adults with type 2 diabetes mellitus. Journal of Diabetes and Its Complications, 26, 10-16. doi:10.1016/j.jdiacomp.2011.11.002.

Bai Y-L, Chiou, C-P., \& Chang, Y-Y. (2009). Self-care behaviour and related factors in older people with type 2 diabetes. Journal of Clinical Nursing, 18, 33083315 . doi: $\quad 10.1111 /$ j.13652702.2009.02992.x.

Bean, D., Cundy, T., \& Petrie, K. J. (2007). Ethnic differences in illness perceptions, self-efficacy and diabetes self-care. Psychology and Health; 22(7), 787-811. doi: 10.1080/14768320600976240.

Gao, J., Wang, J., Zheng, P., Haardörfer, R., Kegler, M. C., Zhu, Y., \& Fu, H. (2013). Effects of self-care, self-efficacy, social support on glycemic control in adults with type 2 diabetes. BMC Family Practice, 14, 66. doi: 10.1186/14712296-14-66.

Hunt, et al. (2012). Relationships among selfefficacy, social support, social problem solving, and self-management in a rural sample living with type 2 diabetes mellitus. Research and Theory for Nursing Practice: An International Journal, 26(2). doi: 10.1891/15416577.26.2.126.

Lee, H., Ahn, S., \& Kim, Y. (2009). Self-care, self-efficacy, and glycemic control of koreans with diabetes mellitus. Asian Nursing Research, 3(3), 139-146. doi: 10.1016/S1976-1317(09)60025-6.

Nyunt, S. W., Howteerakul, N.,Suwannapong, N., \& Rajatanun, T. (2010). Selfefficacy, self-care behaviors and glycemic control among type-2 diabetes patients attending two private clinics in Yangon, Myanmar. Southeast Asian J Trop Med Public Health, 41(4). http://search.proquest.com/docview/7467 77410 ? accountid $=50257$
Sarkar, U., Fisher, L., \& Schillinger, D. (2006). Is self-efficacy associated with diabetes self-management across race/ethnicity and health literacy?. Diabetes Care, 29, 823-829. doi: 10.2337/diacare.29.04.06.dc05-1615.

Sharoni, S. K .A. \& Wu, S. F. V. (2012). Selfefficacy and self-care behavior of Malaysian patients with type 2 diabetes a cross sectional survey. Nursing and Health Sciences, 14, 38-45. doi: 10.1111/j.1442-2018.2011.00658.x. 
Wu S-F. V., Courtney, M., Edwards, H., Mcdowell, J., Shortridge-bagget, L.M., \& Chang, P-J. (2007). Self-efficacy, outcome expectations and self-care behaviour in people with type 2 diabetes in Taiwan.Journal of Nursing and Healthcare of Chronic Illness in association with Journal of Clinical Nursing, 16(11c), 250-257. doi: 10.1111/j.1365-2702.2006.01930.x.

Xu, Y., Pan, W., \& Liu, H. (2010). Selfmanagement practices of Chinese Americans with type 2 diabetes. Nursing and Health Sciences, 12, 228-234. doi: 10.1111/j.1442-2018.2010.00524.x.

Xu, Y., Toobert, D., Savage, C., Pan, W., \& Whitmer, K. (2008). Factors Influencing Diabetes Self-Management in Chinese People With Type 2 Diabetes. Research in Nursing \& Health, 31, 613-625. doi:10.1002/nur.20293. 